\title{
BULGARIA AND THE UKRAINIAN CRISIS: NATIONAL INTERESTS AND POLITICAL INSTITUTIONS
}

Abstract: The Ukrainian crisis is an arena of geopolitical conflict in which the interests of Russia, NATO and the EU intertwine. It is in this context that the behaviour of Bulgarian political institutions has to be analyzed. In the first section, I explore the reactions and positions of the Bulgarian governments, the main political parties and the presidential institution towards the Ukrainian crisis. In the second part, I highlight the tools used by Russia in order to influence Bulgarian political institutions and processes. The third section traces the measures undertaken by the United States and the EU to neutralize Russia's clout. I defend the view that Sofia needs to be more consistent in fulfilling its commitments to NATO and the EU.

Keywords: Bulgaria and the Ukrainian crisis, Russia and political parties in Bulgaria (2013-2020), Russian energy projects and Bulgarian politics

\section{Introduction}

The term 'Ukrainian crisis' describes a series of events: the Euromaidan protests against President Yanukovych, which called for Ukraine's integration into the EU (2013-2014), the change of power in Kyiv (2014) and the subsequent Russian "reaction" (the "annexation" of Crimea, „русская весна" - the "Russian spring” in Donetsk, Luhansk, etc.). Every crisis reflects a state of conflict, violent or not (Brecher, 1996, p. 128). In my opinion, the armed conflict between the pro-Russian rebels and Kyiv, which began in 2014 and continues to this day (despite the Minsk agreements and sporadic ceasefires), is part of the Ukrainian crisis.

The Ukrainian crisis is an arena of geopolitical conflict in which the interests of Russia, NATO and the EU intertwine. It is in this context, that the behaviour of Bulgarian political institutions has to be studied. A key place in this work is allocated to the question of the extent to which Bulgaria's commitments as a member of NATO and the EU are respected, but also how the deep ties between Russia and Bulgaria affect the institutions of the latter.

1 P_Cholakov@yahoo.com 
At prima facie, the national interests of Bulgaria require of its politicians and institutions to strike a balance between NATO, the EU and Russia. But is this 'geopolitical ideal' really feasible? That is the other pressing question that the paper examines.

\section{The policies of Bulgarian institutions}

Bulgaria's policies towards the Ukrainian crisis have gone through several distinct stages. They are shaped by the political dynamics in Kyiv and depend on the changing parliamentary majority in Sofia. At the height of the Maidan protests, the 'strategy' of Bulgarian diplomacy has been characterized as the policy of "doing nothing" (Dimitrov, 2017, p. 96; Kalan, 2015). However, on February 20, 2014 Bulgaria supported the EU Council's decision to impose sanctions on twenty Ukrainian senior government officials found guilty of violence against protesters in Kyiv. Nine of the seventeen Bulgarian MEPs (representatives of GERB, the Blue Coalition and the National Movement for Stability and Progress - NMSP) expressed common support for Maidan protesters and called for the formation of a new unifying government, early elections and constitutional reforms in Ukraine.

Following Yanukovych's escape in late February 2014, Bulgaria expressed its support for the new government in Kyiv. However, Bulgarian authorities were concerned over the situation of the Bulgarian minority in Ukraine, especially in the context of the draft law on minority languages (at the end, the draft was not signed by then President Turchinov). According to data from the population census in Ukraine, conducted in 2001, 204,600 people in the country identified themselves as ethnic Bulgarians (Kuras \& Pirozhkov, 2004).

The 'pro-Putin' party Ataka has criticized the positions of the Ministry of Foreign Affairs and denounced the visit of the Foreign minister Vigenin to Ukraine. But the minister's work has also been under scrutiny by certain circles within his own socialist party - the BSP. The majority of the BSP electorate sympathizes with Moscow in "the Russian-Ukrainian conflict" (Dimitrov, 2017, pp. 96-97). Nonetheless, Mr. Sergey Stanishev, who was at the time BSP's leader, has supported Ukraine's pro-European orientation.

Oresharski's government, President Plevneliev and the PES leader Stanishev have not recognized the outcome of the referendum on Crimea, in which the peninsula voted to join Russia (March 16, 2014). Immediately after the referendum, the EU imposed sanctions on twenty-one Russian and Ukrainian officials, because it was believed that they "facilitated the annexation". However, the referendum was attended - and thus de facto legitimized - by five MPs from Ataka and a journalist from the BSP's newspaper Duma - Alexandar Simov. Referring to the referendum, the publisher of Duma (2008-2015), Nikolai Malinov, congratulated "all Orthodox Slavs" on the "victory in the Third Crimean War" ("A MP from the BSP", 2014).In the years that followed, Mr. Malinov was about to play an important part in the increasingly tense relations between Bulgaria and Russia.

The analysis of the draft resolutions discussed at the Bulgarian National Assembly on the occasion of the Ukrainian crisis is indicative of the stances of the main political parties. The document prepared by the opposition centre-right GERB was "strongly pro-Atlantic", while that of Ataka painted a completely different picture - it presented the Euromaidan protesters as "terrorists", who were instigated by the US Assistant Secretary of State 
Newland. Furthermore, the BSP's plenum did not support the views of party's leader Stanishev regarding the crisis. Instead of the document proposed by Mr. Stanishev, a revised text was adopted at the forum, which did not mention anything about the Russian military units in Crimea (Dimitrov, 2017, p. 100).

The BSP's position on the crisis in Ukraine reflects the attitudes of party's electorate, which has strong sympathies towards Russia; $28 \%$ of BSP voters do not want the country to be a member of the EU, and 40\% do not want Bulgaria in NATO ("Exacta", 2018). The party states that "it is crucial for Bulgaria to reduce the tensions between the Black Sea countries of Ukraine and Russia and to avoid escalation of the confrontation between NATO and Russia in the Black Sea" (BSP: "Vision for Bulgaria", 2019, p. 38). The BSP defends the balance between NATO membership and good relations with the Russian Federation (RF). At the same time, however, the BSP is calling for the lifting of sanctions on Russia, the commissioning of the Belene NPP, which will use Russian nuclear reactors, and the resumption of the gas corridor projects with Russia (Ibid.).

After the resignation of the Cabinet of Oresharski's on August 6, 2014, President Plevneliev appointed a caretaker government (August 6 - November 7, 2014) headed by Prof. Bliznashki. Mr. Daniel Mitov was appointed Foreign Minister and he remained on this post during the next (ordinary) government of the centre-right GERB (November 7, 2014 - January 27, 2017), the second cabinet led by Boyko Borisov. Mitov vouched that Bulgaria was not going to support lifting of sanctions against Russia - "a country that violated international law in the Ukrainian crisis" (Daniel Mitov, 2016).

After the second government of Mr. Borisov resigned in January 2017, the newly elected President Roumen Radev appointed a caretaker government (January 272017 May4, 2017) with Prof. Gerdzhikov serving as Prime Minister.

President Radev, a NATO general and a fighter-jet pilot, who was elected with the support of the BSP, calls for the restoration and improvement of "economic ties between Bulgaria and Russia (Rumen Radev, 2017). He also defends the view that the EU sanctions imposed on Russia must be lifted. Furthermore, the President supports the Turk Stream 2 project and describes the completion of the Belene NPP as "inevitable" (Rusenova, 2019).

In terms of foreign policy, the actions of the cabinet "Borisov" 3 (voted by the parliament on May 4, 2017) are contradictory. On the one hand, Foreign Minister Zaharieva adheres to NATO and EU positions on the conflict in Ukraine. On the other hand, Bulgaria refused to expel Russian diplomats in 2018 because of the Skripal affair. Borisov's GERB is in coalition with the United Patriots, which until September 2019 included the 'pro-Kremlin' Ataka.

The economic effect of Russia's counter-sanctions against Bulgaria, which I will not examine in details here, is a subject of a heated debate. According to Minister Taneva, in 2015 alone, the losses for Bulgarian agriculture from the Russian embargo amounted to 82 million Euros per year (Popov 2015). Some scholars claim that the losses are overestimated: "only two percent of Bulgaria’s small agricultural exports go to the Russian market" (Dimitrov, 2017, p. 104). The crisis mainly affects Bulgarian tourism, the real estate sector, and especially, as we shall see, energy economics. 


\section{Bulgaria and the Russian instruments of influence}

The relations between Bulgaria and the Ukraine "have always been in the shadow of the deep and contradictory trace left in Bulgarian history by Russia" (Dimitrov, 2017, p. 94). In 2015 the Bulgarian President Plevneliev stated that Russia aims at the destabilization not only of NATO member Bulgaria, but the Balkans as a whole, through "a hybrid campaign" (Holmes 2015). In the words of General Gerasimov, the Chief of the Russian Armed Forces, the "hybrid warfare" requires the army to combine "its classical potential with the asymmetric one" (Gerasimov, 2013, Trenin, 2019).

At a certain level, in Bulgaria, the "fear" of Russia is disproportionately great; there are no conditions for a comprehensive "hybrid scenario" as in Ukraine (Bechev 2017, p. 192). In Bulgaria, unlike Ukraine, Estonia, Latvia, etc., there is no significant Russian-speaking minority. Moscow relies most of the time on "co-opting" instead of "forcing" the local elite (Ibidem). Against NATO countries, such as Bulgaria, "softer" instruments are used, that have been applied since 'the socialist era': active measures, infiltration of state institutions, security services and local political and economic structures; misinformation; cyber attacks, etc. (Ibidem).

The use of disinformation by Russia is easier to prove than the other 'tools'. Much more difficult to verify are the cases of local actors 'hired' by Russia (Bechev, 2017, p. 192). There are, at least, two groups of Russian 'Trojan horses': first, protest movements, and activists; second, ultranationalist, far-right parties and organizations, but also left-wing and far-left formations that oppose NATO and the EU (Bechev, 2017, p. 192; Cholakov, 2018, pp. 112-120). It is believed that Russia can rely on the BSP, MRF, Ataka, Volya and other formations (Cholakov, 2018). Of particular importance, but also difficult to verify and, therefore, often the subject of anecdotal evidence, are cyber attacks and operations by Russian special services.

One example, reflected in a report by the Bulgarian State National Security Agency (SNSA) which seems to point that Russia holds the smoking gun, dates back to October 25,2015 . Immediately after the local elections, the websites of the Central Elections Commission, the Ministry of the Interior, the SNSA, the parliament and the presidency were all subjected to cyber attacks.

In my view, the biggest threat which Russia poses to Bulgaria is not its military machine or propaganda, but in the corruption which is widespread in Bulgaria's political system and the means by which the Kremlin attempts to benefit from this corruption. State capture works in favour of Russian interests (Bechev, 2017, Galeotti, 2017). Illegal practices, such as non-payment of taxes, the formation of cartels, etc., are common for companies patronized by the powers that be in Bulgaria. The Kremlin uses practices such as political appointments in state-owned companies, corrupt public procurement, lack of transparency and public control over political decisions (Bechev, 2017, p. 214).

While I agree with Bechev that, in the past, Russia preferred to rely on the use of "soft" tools in the case of Bulgaria, more recently there is evidence that Russia is using increasingly more aggressive instruments (see, for example, the 'Geber' affair, below). Furthermore, the polarization between the Kremlin, on the one hand, and Washington and Brussels, on the other, is intensifying.

There have been allegations - primarily on behalf of the centre-right GERB - that the Kremlin was instrumental in the selection of Mr. Radev as the presidential candidate 
to receive the support of the BSP ("Who is Reshetnikov and for which investigation were the Russophiles questioned”, 2019). Some even suggest that Radev was hand-picked by the socialist party under the influence of the former director of the Russian Institute for Strategic Studies (RISS) - General Leonid Reshetnikov (Ibidem).

Radev is not only in favour of Russia's energy projects and supports the lifting of sanctions imposed on the Kremlin, but he also vetoed a deal initiated by the third cabinet of Borisov to purchase eight US F-16 fighter jets. However, it is bizarre why - if Mr. Radev was indeed 'chosen' by the Kremlin - General Reshetnikov shall seek to disclose this, supposedly, top-secret 'information'. In my opinion, the behaviour of Reshetnikov is, actually, indicative of something else: it would be flattering for Russia's reputation if one was to succeed in convincing the world that the Kremlin has 'selected' the president of a NATO country. Reshetnikov's eagerness to 'share' this 'breakthrough', however, rather points at the opposite - that these are merely insinuations.

In the fall of 2017, GERB accused Radev of lobbying for the purchase of Swedish Saab's Gripen fighter jets for the Bulgarian army. The fact of the matter is that the caretaker government, appointed by Radev, ranked Saab's offer first. A parliamentary committee was set up in the autumn of 2017 to investigate the case, but - three years later -no charges were brought against the president. Either the 'Gripen' affair is a speculation, or Radev's critics prefer to keep the topic as an 'ace up their sleeve'. However, the latter is unlikely, given the conflict between Radev and Borisov, which escalated in 2020.

In October 2020 in Estonia, Radev expressed his strong support for the Three Seas Initiative, the patron of which is the United States (Engdahl, 2018). President Trump wants to detach the countries in the region from their energy dependence on Russia. The forum defends the energy diversification of the region in order to decrease the significance of Russia's clout, and promotes, for example, the supply of countries such as Poland with American liquefied natural gas (LNG). If Radev is under the influence of the Kremlin, his support for Three Seas Initiative is, to say the least, inexplicable.

At the same time, it seems that some of the activities of Reshetnikov have a direct bearing on the Ukrainian crisis. He is the initiator of the Two-Headed Eagle Society (established in 2016), which is funded by Konstantin Malofeev, a 45-year-old oligarch and defender of the "orthodox", "conservative values" ("Who is Reshetnikov..." 2019). In 2014, Ukraine launched a criminal investigation against Malofeev for funding "illegal military groups" (i.e. the Russian separatists) in the eastern part of the country; Malofeev's name is also included in the EU sanctions list (Ibid.).

In the 'Gebrev' affair there are allegations of actions by GRU agents in Bulgaria. The arms dealer Emilian Gebrev believes that an attempt was made in 2015 to poison him with Novichok. He has linked this case to the poisoning of Sergei and Yulia Skripal in Salisbury (2018). One version - supported by Gebrev himself - is that he was attacked by the Kremlin because he exported weapons to Ukraine and, thus, harmed Russian interests (Gunkel, 2020).

In September 2019, the Bulgarian prosecution accused the leader of National Movement "Russophiles" (NMR) Nikolai Malinov and other key members of the organization in espionage on behalf of Russia. General Reshetnikov was banned from entering Bulgaria for ten years. The prosecution claims that there is evidence that Malinov accepted "for a fee to perform tasks from RISS and the Double-Headed Eagle Society", among which were: "the development of a political party", the establishment of "an influential television", etc. 
in order to change the "geopolitical orientation of the country" (Cholakov, 2020b). Malinov has met repeatedly with Reshetnikov and Malofeev. According to the prosecution, Mr. Malinov has stated in a "report": "We have taken action to transfer half a billion from Tsvetan Vassilev [the majority owner of the bankrupt Corporate Commercial Bank - CCB, who is currently hiding from the Bulgarian prosecution in Serbia] to the Russian businessman Malofeev" (Ibid.).

In September, 2020 Malinov has announced his intention to create and lead a new Bulgarian "Russophile" party by the end of 2020. The future party shall take part in the next parliamentary elections (that are due in the spring of 2021). This news seemed to corroborate the thesis of the prosecution against Mr. Malinov. The political platform of the new formation remains to be seen, but, given Malinov's close ties to Moscow ("Who is Reshetnikov...", 2019), it is more appropriate to dub this project a 'pro-Putin' or a 'pro-Kremlin party" instead of a "Russophile" formation.

Hours after Mr. Malinov made public his political ambitions, the Bulgarian Foreign Ministry accused two Russian diplomats of espionage and declared them personae non gratae (Drumeva\&Ginkova, 2020). According to the prosecution, they were looking for information about plans to modernize the Bulgarian army and improve the maintenance of the military equipment (Ibid.). In October 2020, Russia, which denied the allegations, took a reciprocal measure and expelled Bulgarian diplomats. Earlier in 2020, there was a similar case. In January, Bulgaria expelled two Russian diplomats suspected of collecting data on Bulgaria's national elections and energy security ("Lavrov called the Bulgarian ambassador to Russia”, 2020).

\section{The role of the US and the EU in neutralizing Russian influence}

It is possible that the Bulgarian institutions have finally decided to deal with the instruments of Russian influence in Bulgaria under pressure from the United States. This political behaviour should be seen in the light of the fact that the relations between NATO and Russia are at their lowest point in years.

In a speech delivered at the Atlantic Club in November 2019, US Ambassador to Bulgaria Herro Mustafa said that the United States was ready to sanction corrupt Bulgarian officials (e.g. government officials, MPs, senior judges, attorneys, etc.) and their families. According to Mrs. Mustafa, those measures "will benefit Bulgaria in the long run, as strict adherence to the rule of law is inextricably linked to Bulgaria's political and economic prosperity" (Cholakov, 2019a).

In October 2019, the suspected espionage leader of the 'Russophiles' movement was released by Judge Andon Mitalov to travel to Russia for five days without the consent of the prosecutor's office. An unprecedented reaction from the State Department followed: in February 2020, Mitalov became the first high-ranking Bulgarian to be sanctioned by Washington for corruption.

Judge Mitalov's conduct can be seen as an argument in support of the allegations that Russia has influence over the judiciary in Bulgaria. The former Foreign Minister Mitov believes that - because of his firm pro-NATO positions, e.g. regarding the Ukrainian crisis and the war in Syria - he became a victim of unfounded, unproven accusations by the Bulgarian prosecutor's office; in his view, the prosecution acted under pressure from the 
Kremlin (Mitov, 2020). It is indicative, that the accusations against Mitov were dismissed by the court and he was acquitted in April, 2020.

The Bulgarian prosecutor's office has been silent for years regarding the allegations of possible Russian involvement in Gebrev's poisoning. It was only in 2019 that the then Chief Prosecutor Tsatsarov commented on the case, saying that Gebrev had been poisoned with an "insecticide" (Veselinova, 2019). Later, however, the prosecutor's office abruptly changed its version and accused three Russians of trying to poison Gebrev.

In this regard, we must also mention the MRF (Movement for Rights and Freedoms). While on 'the surface', this is a liberal and pro-Atlantic formation, for years there have been claims that this ethnic party in fact serves Russia's geopolitical interests in Bulgaria (Cholakov, 2018, Minchev, 2016). The MRF is believed to have a strong influence in the country's judiciary.

Mustafa's speech in Bulgaria's Atlantic Club is important for at least two reasons. Firstly, in my view, it contains the assessment that Bulgaria has a systemic problem with corruption at the highest levels of government. This claim is corroborated by the facts Bulgaria has been constantly ranked as the most corrupt EU state in the Corruption Perception Index (CPI) of Transparency International (Transparency International, 2020). Ms. Mustafa's words, which are, of course, an expression of the official American position, contrast sharply with Borisov's government attempts to downplay Bulgaria's corruption problem. Secondly, Ms. Mustafa's speech suggests that, according to the United States, Bulgaria lacks the political will to tackle the metastases of corruption. The Bulgarian authorities have shown that they cannot (or do not want to) be 'cured'.

While the evidence on Russia's interference in the judiciary is disputable, Kremlin's leverage over Bulgaria's energy industry is a well-known fact.

The dictum of Emperor Alexander III "Russia has only two allies: the army and the navy" is well known. But, from the point of view of modern political realities, we can point out a third ally - the hydrocarbons. Energetics is Moscow's main geopolitical tool for influence. Bulgaria's energy industry is highly dependent on Russia: the country imports more than two thirds of the natural gas that it consumes (Cholakov, 2019d, Shentov, 2018). Lukoil Bulgaria, which is part of the Russian Lukoil Group, is the largest company in Bulgaria (it accounts for about 9\% of GDP). In 2011 the then head of Lukoil-Bulgaria Mr. Zlatev became a mediator in the negotiations for the construction of Belene NPP. The Government of the Russian Federation has repeatedly expressed its strong support for the project (Bechev, 2017, Shentov, 2018).

At the end of the first decade of 2000, Bulgaria played a key role in the Kremlin's efforts to build a gas corridor through south-eastern Europe to bypass Ukraine - that was the intent behind the Blue Stream, Nord Stream and South Stream projects. Bulgaria was among the countries heavily affected by the Second Ukrainian Gas Crisis (January 6-20, 2009). Along with South Stream, two other ambitious projects, part of Russia's geopolitical game, are the construction of the Belene NPP and the Burgas-Alexandroupolis oil pipeline.

South Stream would probably have taken place had it not been for the Ukrainian crisis, in particular the annexation of Crimea by Russia. The crisis hampered reaching a compromise agreement between Gazprom and the European Commission (EC) on implementing EU rules on third-party access to South Stream. As a result, Prime Minister Oresharski announced that work on South Stream will be frozen until an agreement is reached 
between Russia and the EC. It is possible that the fate of South Stream became a catalyst for the political crisis that started in Bulgaria in June 2014 (Bechev, 2017). It led to the break-up of the ruling coalition, after the MRF withdrew its support for the Oresharski's government, and the early parliamentary elections in the autumn of 2014, which brought GERB back to power.

The bankruptcy of CCB has also been linked to the shutdown of the South Stream project. CCB's main partner - the MRF's politician and tycoon Delyan Peevski - has taken out significant loans from the bank with the intention of participating in the construction of South Stream (Bechev, 2017, p. 107). It is possible, that after the project failed, Mr. Peevski bankrupted the CCB, because he was not able to repay the loans (Ibid.). It is also worth noting that there is evidence that Mr. Malofeev was trying to acquire TV7 - a CCB's sponsored TV channel (Ibid.).

South Stream's fiasco has not ended Bulgaria’s dependence on Russian energy. However, there are certain barriers to the effectiveness of Russia's 'energy weapon'. Changing market conditions and pressure from Brussels to liberalize and diversify gas supplies are reducing the weight of this instrument. Gazprom has been targeted by the EU, which in 2015 filed a lawsuit against the company for violating antitrust laws.

In October 2020, Francis Fannon, the US Assistant Secretary of State for Energy, has said that the project, which Prime Minister Borisov persistently calls "the Balkan Stream", is in fact a part of Turk Stream 2 ("The US remain against the Belene NPP...", 2020). The United States opposes this project, as well as the revival of Belene NPP. Washington expanded the sanctions against Turk Stream 2 and Nord Stream 2 companies and gave them a month to leave the two projects (Karaboev, 2020).

There is evidence that in Bulgaria Turk Stream 2 is being built by Russia, which has taken over the Saudi Arcade Consortium and has hired subcontractors related to Gazprom (Stanchev, 2020). Bulgartransgaz (Bulgaria's state-owned grid operator) is the owner of the new East-West pipeline (the part of the Turk Stream 2 in Bulgaria). In essence, the costs of BGN 3 billion for this pipeline are paid by the Bulgarian taxpayers. They are not going to receive back their 'investment' in the foreseeable future, since Gazprom has booked close to 90 percent of the throughput capacity over the next 20 years. In short, the claims of the Bulgarian government that it is working for energy diversification, i.e. for reducing the dependence of the Bulgarian energy sector on Russia, are false.

\section{Conclusions}

The reaction of the Bulgarian political system to the crisis in Ukraine is part and parcel of the everlasting question regarding the role of Russia in the Bulgarian politics. Unlike the Bulgarian governments, which - at least on the surface - adhere to the positions of the EU and NATO on the Ukrainian crisis, there is discord in the presidential institution. The contrast between the political agendas of Presidents Plevneliev and Radev is impossible to omit: one is a zealous Atlanticist, the other - a supporter of the foreign policy balance.

Bulgaria must take care to protect the rights and interests of the Bulgarian minority in Ukraine. In this sense, the stance of Bulgarian parliament against the planned administrative reform in Odessa in May 2020 was well-judged and appropriate. For Sofia the peaceful resolution of the conflict in the Black Sea is important. It is also clear, given the deep 
economic and cultural ties between Bulgaria and Russia, that Bulgaria has much to lose from the deterioration of the relations between Sofia and Moscow.

While examining the policies of Radev and Borisov, we are left with the impression that Bulgarian institutions often attempt to appease both Moscow and Washington. This paradoxical dichotomy reflects the attitudes of a large part of Bulgarian voters. At the beginning of 2015, 74\% of Bulgarians assessed the government's policy towards the Ukrainian crisis as "moderate and balanced" (Alpha Research, 2015). However, a Pew Research Centre study conducted in nineteen countries, sixteen of which are members of NATO, shows that Bulgaria is the country that prefers ties with Russia to those with the United States (Fagan\&Poushter, 2020). Two-thirds of Bulgarians reject the country's military intervention in support of a NATO ally "in the event of Russian aggression" (Ibid.). Furthermore, Bulgarians turn out to be 'champions' in 'liking Putin' - as many as $62 \%$ "have confidence" in the Russian president (Ibid.).

However, how realistic is it for Bulgarian foreign policy to be guided by the principle 'always with NATO, never against Russia'?

The country has already made its choice; the geopolitical dice has been cast: Bulgaria has been a member of NATO since 2004 and of the EU since 2007. Both the Atlantic Pact and the EU condemn Moscow's role in the Ukrainian conflict. At the same time, allegations of Kremlin's interference in the political processes in the United States and elsewhere, the 'Skripal' affair, the uncovered base of Russian spies in the Alps in 2019, the mutual accusations over the poisoning of Russian opposition leader Navalny in the summer of 2020, and other events show that tensions between Russia, on the one the hand, and Brussels and Washington, on the other, are growing.

Bulgaria increasingly looks like a front-line state on the territory of which the clash between the Alliance and the Kremlin is taking place.

Bulgaria should not sever all its ties with Russia, nor kneel before its 'new' foreign policy partners. However, Sofia must realize that the deepening inter-bloc animosity makes the ambiguous foreign policy positions highly inappropriate. Bulgaria should adhere more strictly to the course adopted by NATO and the EU, and, in particular, can benefit from the release of its energy industry from Moscow's 'custody'. 
Петар Г. Чолаков ${ }^{1}$

Бугарска академија наука,

Институт за филозофију и социологију

Софија (Бугарска)

\title{
БУГАРСКА И КРИЗА У УКРАЈИНИ: НАЦИОНАЛНИ ИНТЕРЕСИ И ПОЛИТИЧКЕ ИНСТИТУЦИЈЕ
}

\author{
(Превоg In Extenso)
}

Сажетак: Украјинска криза је арена геополитичког сукоба у којем се преплићу интереси Русије, НАТО и ЕУ. Понашање бугарских политичких институција мора се анализирати управо у овом контексту. У првом одељку истражујем реакције и ставове бугарске владе, главних политичких партија и председника о украјинској кризи. У другом делу истичем алатке које Русија користи да би утицала на бугарске политичке институције и процесе. Трећи део бави се мерама које су предузеле Сједињене Америчке Државе и ЕУ да би неутралисале утицај Русије. Заступам став да Софија треба да буде доследнија у испуњавању својих обавеза према НАТО и ЕУ.

Кључне речи: Бугарска и криза у Украјини, Русија и политичке партије у Бугарској (2013-2020), руски енергетски пројекти и бугарска политика

\section{Увод}

Термин „украјинска криза” описује низ догађаја: Евромајдан протесте против председника Јануковича, који су захтевали интеграцију Украјине у ЕУ (2013-2014), затим смену власти у Кијеву (2014) и каснију „реакцију” Русије („анексија” Крима, „русская весна”, односно „руско пролеће” у Доњецку, Луганску итд.). Свака криза одражава стање сукоба, био он насилан или не (Brecher, 1996, p. 128). По мом мишљењу, оружани сукоб између проруских побуњеника и Кијева, који је избио 2014. године и траје до данас (и поред Минског протокола и спорадичних прекида ватре), представља део украјинске кризе.

Украјинска криза је арена геополитичког сукоба у којем се преплићу интереси Русије, НАТО и ЕУ. Понашање политичких институција Бугарске мора се проучити управо у овом контексту. Кључно место овог рада дато је питању степена у којем се испуњавају обавезе Бугарске као чланице НАТО и ЕУ, али и у којој мери чврсте везе између Русије и Бугарске утичу на бугарске институције. На први поглед, национални интереси Бугарске захтевају од њених политичара и институција да успоставе равнотежу између НАТО, ЕУ и Русије. Али да ли је овај „геополитички идеал” заиста изводљив? То је друго горуће питање које овај рад истражује.

1 P_Cholakov@yahoo.com 


\section{1. Политика бугарских институција}

Политика Бугарске у односу на украјинску кризу прошла је кроз неколико различитих фаза. Ту политику обликује политичка динамика у Кијеву и она зависи од променљиве парламентарне већине у Софији. На врхунцу протеста на Мајдану, „стратегија” бугарске дипломатије оцењена је као политика „не радити ништа” (Dimitrov, 2017, str. 96; Kalan, 2015). Међутим, 20. фебруара 2014. године Бугарска је подржала одлуку Савета ЕУ о увођењу санкција против двадесеторице високих украјинских функционера који су окривљени за насиље над демонстрантима у Кијеву. Девет од седамнаест бугарских посланика у Европском парламенту (представника ГЕРБ-а, Плаве коалиције и Националног покрета за стабилност и напредак) дало је подршку демонстрантима на Мајдану и позвало на формирање нове ујединитељске владе, превремене изборе и уставне реформе у Украјини.

После Јануковичевог бекства крајем фебруара 2014, Бугарска је дала своју подршку новој влади у Кијеву. Упркос томе, бугарске власти биле су забринуте због ситуације у којој се нашла бугарска мањина у Украјини, нарочито у контексту нацрта закона о језицима мањина (на крају, тадашњи украјински председник Турчинов није потписао овај нацрт). Према подацима из пописа становништва у Украјини спроведеног 2001. године, 204.600 људи у тој земљи изјаснили су се као етнички Бугари (Kuras \& Pirozhkov, 2004).

Пропутинова странка Атака критиковала је ставове Министарства иностраних послова и осудила посету министра иностраних послова Вигенина Украјини. Исто тако, министров рад нашао се и под лупом одређених кругова у његовој Бугарској социјалистичкој партији (БСП). Већина бирача БСП-а гаји симпатије према Москви у „руско-украјинском сукобу” (Dimitrov, 2017, str. 96-97). Упркос томе, господин Сергеј Станишев, који је у то време био на челу БСП-а, подржао је проевропску оријентацију Украјине.

Влада Пламена Орешарског, председник Плевнелијев и лидер Партије европских социјалиста Станишев нису препознали исход референдума на Криму, на којем је ово полуострво гласало за припајање Русији (16. март 2014). Одмах после референдума ЕУ је увела санкције против двадесет једног руског и украјинског званичника зато што се веровало да су „олакшали анексију”. Међутим, референдуму су присуствовали - и самим тим заправо и дали легитимитет - петорица посланика из партије Атака и Александар Симов, новинар из Думе, гласила БСП-а. Говорећи о референдуму, издавач Думе (2008-2015) Николај Малинов честитао је свим „православним Словенима" на „победи у Трећем кримском рату" ("А MP from the BSP”, 2014). Током наредних година, господин Малинов ће имати значајну улогу у све затегнутијим односима између Бугарске и Русије.

Анализа нацрта резолуција о којима се расправљало у Народној скупштини Бугарске поводом украјинске кризе јасно указује на ставове главних политичких партија. Документ који је саставио опозициони десни центар ГЕРБ био је „снажно проатлантски”, док је став партије Атака био сасвим другачији - Атака је Евромајдан демонстранте представила као „терористе” које хушка Викторија Нуланд, заменица државног секретара САД. Поред тога, пленум БСП-а није подржао ставове које је о 
кризи имао лидер те партије Станишев. Уместо документа који је предложио господин Станишев, на форуму је усвојен ревидирани текст у којем се уопште не помињу руске војне јединице на Криму (Dimitrov, 2017, str. 100).

Став БСП-а о кризи у Украјини одражава расположење гласача ове партије који гаје велике симпатије према Русији; 28\% гласачког тела БСП-а не жели да њихова земља буде чланица ЕУ, док 40\% не жели да Бугарска буде чланица НАТО ("Ехасta", 2018). Ова партија изјавила је да је „за Бугарску пресудно да смањи тензије између црноморских земаља Украјине и Русије како би се спречила ескалација конфронтације између НАТО и Русије на Црном мору" (BSP: "Vision for Bulgaria", 2019, str. 38). БСП заговара равнотежу између чланства у НАТО и добрих односа са Руском Федерацијом (РФ). Међутим, БСП истовремено позива на укидање санкција Русији, пуштање у рад нуклеарне централе Белене која ће користити руске нуклеарне реакторе, као и на наставак пројеката за гасни коридор са Русијом (Ibid.).

После оставке кабинета Пламена Орешарског 6. августа 2014, председник Плевнелијев је именовао прелазну владу (6. август - 7. новембар 2014) са професором Близнашким на челу. Господин Данијел Митов изабран је за министра иностраних послова и на том положају је остао и током мандата следеће (редовне) владе десног центра ГЕРБ (7. новембар 2014 - 27. јануар 2017), где је други кабинет предводио Бојко Борисов. Митов је обећавао да Бугарска неће подржати укидање санкција против Русије - „земље која је прекршила међународно право у украјинској кризи” (Daniel Mitov, 2016).

Када је у јануару 2017. друга влада премијера Борисова поднела оставку, новоизабрани председник Румен Радев именовао је прелазну владу (27. јануар 2017 4. мај 2017) чији је премијер био професор Герџиков.

Председник Радев, НАТО генерал и пилот борбеног авиона, који је изабран уз подршку БСП-а, позвао је на обнављање и побољшање „економских веза између Бугарске и Русије (Rumen Radev, 2017). Он је такође заговарао став да се морају укинути санкције које је ЕУ увела Русији. Осим тога, председник је подржао пројекат Турски ток 2, а завршетак радова на нуклеарној централи Белене оценио као „неизбежан" (Rusenova, 2019).

Када је реч о спољној политици, поступци трећег кабинета премијера Борисова (који је изгласан у парламенту 4. маја 2017) су противречни. С једне стране, министарка иностраних послова Захаријева подржала је ставове НАТО и ЕУ о сукобу у Украјини. Бугарска је, с друге стране, одбила да 2018. протера руске дипломате због афере Скрипаљ. Борисовљева партија ГЕРБ била је у коалицији са Уједињеним патриотама, да би се у септембру 2019. коалицији придружила и „прокремљ” партија Атака.

Економски ефекат контрасанкција које је Русија увела Бугарској, а које овде нећу детаљно разматрати, предмет је жестоке расправе. Према министарки Таневој, само 2015. године су губици бугарске пољопривреде услед руског ембарга достигли 82 милиона евра (Popov 2015). Поједини стручњаци тврде да су ти губици прецењени: „само два процента малих извозника пољопривредних производа Бугарске усмерено је на руско тржиште" (Dimitrov, 2017, str. 104). Криза углавном погађа бугарски туризам, сектор некретнина, а нарочито економију енергетике, о чему ће бити речи у наставку. 


\section{2. Бугарска и руски инструменти утицаја}

Односи између Бугарске и Украјине „одувек су били у сенци дубоког и противречног трага који је Русија оставила у бугарској историји” (Dimitrov, 2017, str. 94). Године 2015. бугарски председник Плевнелијев изјавио је да Русија има за циљ да дестабилизује не само Бугарску као чланицу НАТО, већ и Балкан у целини, путем „хибридне кампање” (Holmes, 2015). Према речима генерала Герасимова, начелника Генералштаба Оружаних снага Руске Федерације, „хибридно ратовање” захтева од армије да удружи „свој класични потенцијал са асиметричним” (Gerasimov, 2013; Trenin, 2019).

На одређеном нивоу, у Бугарској влада несразмерно велики „страх” од Русије; не постоје услови за свеобухватни „хибридни сценарио” као у Украјини (Bechev, 2017, str. 192). За разлику од Украјине, Естоније, Летоније итд., у Бугарској нема значајне мањине која говори руски језик. Москва се готово све време ослања на „кооптирање” уместо на „форсирање” локалне елите (Ibidem). Против чланица НАТО, као што је Бугарска, употребљавају се „мекши” инструменти који се примењују још од „социјалистичке ере”: активне мере, инфилтрација државних институција, безбедносних служби и локалних политичких и привредних структура; дезинформисање; сајбер напади итд. (Ibidem).

Руску употребу дезинформација лакше је доказати него остале „алатке”. Много теже је потврдити случајеве локалних актера које Русија „унајмљује” (Bechev, 2017, str. 192). Постоје најмање две групе руских „тројанских коња”: у првој су протестни покрети и активисти; у другој су ултранационалисти и партије и организације крајње деснице, али и левичарске и крајње левичарске формације су против НАТО и ЕУ (Bechev, 2017, str. 192; Cholakov, 2018, str. 112-120). Верује се да се Русија може ослонити на БСП, ДПС, Атаку, Вољу и остале формације (Cholakov, 2018). Од посебног значаја су и сајбер напади и операције руских специјалних служби, али је њих тешко доказати те се, самим тим, често јављају само у анегдотама.

На пример, у извештају Бугарске агенције „Национална сигурност” (ДАНС) од 25. октобра 2015. године наведена је тврдња да Русија поседује необориве инкриминишуће доказе. Одмах после локалних избора, интернет странице Главне изборне комисије, Министарства иностраних послова, ДАНС-а, парламента и председништва нашле су се на мети сајбер напада.

По мом мишљењу, највећа претња коју Русија представља за Бугарску није у њеној војној машинерији или пропаганди, већ у корупцији која је распрострањена у политичком систему Бугарске и у средствима помоћу којих Кремљ покушава да искористи ову корупцију. Заробљавање државе као врста корупције ради у корист руских интереса (Bechev, 2017; Galeotti, 2017). Нелегалне праксе попут неплаћања пореза, стварања картела итд. уобичајене су за компаније које су под заштитом сила које делују у Бугарској. Кремљ користи праксе као што су политичка именовања у државним компанијама, корумпирање јавних набавки, недостатак транспарентности и контроле јавности над политичким одлукама (Bechev, 2017, str. 214).

Иако се слажем са Бечевим да се у прошлости Русија радије ослањала на употребу „меких” алатки када је реч о Бугарској, у последње време постоје докази да Русија користи све агресивније инструменте (видети, на пример, аферу Гебрев, у наставку). Надаље, све је снажнија поларизација између Кремља, с једне стране, и Вашингтона и Брисела, с друге. 
Чују се и оптужбе - првенствено на рачун десног центра ГЕРБ - да је Кремљ имао кључну улогу у одабиру господина Радева за председничког кандидата који ће добити подршку БСП-а ("Who is Reshetnikov and for which investigation were the Russophiles questioned", 2019). Неки чак тврде да је Радева специјално одабрала Социјалистичка партија под утицајем бившег директора Руског института за стратешке студије (РИСС) - генерала Леонида Решетњикова (Ibidem).

Радев не само да подржава енергетске пројекте Русије и укидање санкција уведених против Кремља, већ је ставио и вето на договор који је покренуо трећи кабинет премијера Борисова за куповину осам америчких борбених авиона Ф-16. Међутим, бизарно је због чега је - ако је господина Радев заиста „изабрао” Кремљ - генерал Решетњиков настојао да обелодани ову наводно строго поверљиву „информацију”. Мишљења сам да понашање генерала Решетњикова, у ствари, указује на нешто друго: за репутацију Русије било би ласкаво ако би некоме пошло за руком да убеди свет како је Кремљ „изабрао” председника једне државе чланице НАТО. Жеља Решетњикова да „подели” ово „откриће”, међутим, пре указује на супротно да су у питању само инсинуације.

У јесен 2017. године ГЕРБ је оптужио Радева да лобира за набавку борбених авиона Грипен од шведске компаније Саб за потребе бугарске војске. Чињеница је да је прелазна влада коју је именовао Радев дала приоритет понуди компаније Саб. У јесен 2017. основан је парламентарни одбор који ће истражити случај, али - ни три године касније - нису подигнуте никакве оптужбе против председника. Могуће је да је афера „Грипен” била измишљена или пак критичари Радева више воле да ову тему сачувају као главни адут. Међутим, ово друго је мало вероватно, имајући у виду сукоб између Радева и Борисова који је ескалирао 2020. године.

Радев је у Естонији октобра 2020. изразио снажну подршку Иницијативи три мора под покровитељством Сједињених Америчких Држава (Engdahl, 2018). Председник Трамп желео је да земље у овом региону учини енергетски независнима од Русије. Форум је заступао енергетску диверсификацију региона како би се смањио значај руске моћи и залагао се за снабдевање земаља, на пример Пољске, течним природним гасом из Америке. Уколико је Радев под утицајем Кремља, његова подршка Иницијативи три мора је, најблаже речено, необјашњива.

Истовремено се чини да поједине активности Решетњикова имају директан утицај на украјинску кризу. Он је покретач Друштва двоглавог орла (основаног 2016), које финансира Константин Малофејев, четрдесетпетогодишњи олигарх и заговорник „православних”, „конзервативних вредности” ("Who is Reshetnikov...” 2019). Украјина је 2014. покренула кривичну истрагу против Малофејева због финансирања „илегалних војних група” (тј. руских сепаратиста) у источном делу земље; његово име наведено је и на списку санкција које је увела ЕУ (Ibid.).

У афери Гебрев помињу се наводи о деловању агената руске Главне обавештајне управе (ГРУ) у Бугарској. Трговац оружјем Емилијан Гебрев верује да је 2015. године избегао покушај тровања нервним агенсом новичок. Он је овај случај повезао са тровањем Сергеја и Јулије Скрипаљ у Солзберију (2018). Једна верзија - коју подржава и сам Гебрев - јесте да се нашао на мети Кремља због тога што је извозио оружје у Украјину и тако угрожавао руске интересе (Gunkel, 2020).

У септембру 2019. је бугарско тужилаштво оптужило Николаја Малинова, вођу Националног покрета русофила, и остале главне чланове организације за шпијунажу 
у корист Русије. Генералу Решетњикову забрањен је улазак у Бугарску наредних десет година. Тужилаштво тврди да постоје докази о томе да је Малинов прихватио да „за накнаду обавља задатке добијене од РИСС-а и Друштва двоглавог орла”, између осталог: „стварање политичке партије”, оснивање „утицајне телевизије” итд., како би се променила „геополитичка оријентација земље” (Cholakov, 2020b). Малинов се у више наврата састајао са Решетњиковим и Малофејевим. Према наводима тужилаштва, Малинов је у „Извештају” изјавио: „Предузели смо мере за пренос пола милијарде од Цветана Василева [већинског власника Корпоративне комерцијалне банке у стечају, који се тренутно крије од бугарског тужилаштва у Србији] руском бизнисмену Малофејеву” (Ibid).

У септембру 2020. Малинов је објавио своју намеру да оснује и предводи нову бугарску „русофилску” партију до краја 2020. године. Будућа партија ће учествовати у наредним парламентарним изборима (који су планирани за пролеће 2021). Ова вест је очигледно подржала претпоставку о оптужбама против Малинова. Политичка платформа нове формације тек треба да буде представљена, али, имајући у виду блиске безе између Малинова и Москве (Who is Reshetnikov..., 2019), много је адекватније назвати овај пројекат „пропутиновом” или „прокремљ” партијом уместо „русофилском” формацијом.

Свега неколико сати после најаве политичких амбиција господина Малинова, Министарство иностраних послова Бугарске оптужило је двојицу руских дипломата за шпијунажу, прогласивши их за personae non gratae (Drumeva\&Ginkova, 2020). Према тужилаштву, они су тражили информације о плановима за модернизацију бугарске војске и побољшано одржавање војне опреме (Ibid.). У октобру 2020. Русија je, поричући ове наводе, применила реципрочну меру протеравши двојицу бугарских дипломата. Сличан случај забележен је и раније исте године. Наиме, у јануару 2020. је Бугарска протерала двојицу руских дипломата осумњичених за сакупљање података о националним изборима у Бугарској и о енергетској безбедности (Lavrov called the Bulgarian ambassador to Russia, 2020).

\section{3. Улога САД и ЕУ у неутралисању утицаја Русије}

Могуће је да су бугарске институције одлучиле да се под притиском Сједињених Америчких Држава коначно позабаве инструментима руског утицаја у Бугарској. Овакво политичко поступање требало би сагледати у светлу чињенице да су односи између НАТО и Русије на најнижем нивоу у последњих неколико година.

У говору који је одржала у Атлантском клубу у новембру 2019, амбасадорка САД у Бугарској Херо Мустафа рекла је да су Сједињене Америчке Државе спремне да санкционишу корумпиране бугарске званичнике (нпр. функционере у влади, посланике, високе судије, адвокате итд.) и њихове породице. Према госпођи Мустафа, те мере „биће од користи Бугарској на дугорочном плану јер је строго поштовање владавине права нераскидиво повезано са политичким и економским просперитетом Бугарске" (Cholakov, 2019a).

У октобру 2019. је судија Андон Миталов, без сагласности тужилаштва, дозволио вођи покрета русофила, претходно осумњиченом за шпијунажу, да отпутује у Русију на пет дана. Реакција америчког Стејт департмента која је уследила била је без преседана: у фебруару 2020. Миталов је постао први бугарски високи функционер кога је Вашингтон санкционисао због корупције. 
Поступак судије Миталова може се посматрати као аргумент у прилог наводима да Русија има утицај над правосуђем у Бугарској. Бивши министар иностраних послова Данијел Митов верује да је - управо због својих чврстих ставова у корист HATO, нпр. у вези са украјинском кризом и ратом у Сирији - постао жртва неоснованих и недоказаних оптужби бугарског тужилаштва. По његовом мишљењу, тужилаштво је поступало под притиском Кремља (Mitov, 2020). Индикативно је и то што је надлежни суд одбацио оптужбе против Митова и што је он ослобођен у априлу 2020. године.

Бугарско тужилаштво је годинама ћутало у вези са наводима о могућој укључености Русије у покушај тровања Гебрева. Тадашњи главни тужилац Цацаров је тек 2019. године прокоментарисао овај случај, изјавивши да је Гебрев отрован „инсектицидом" (Veselinova, 2019). Међутим, касније је тужилаштво изненада променило своју верзију догађаја и оптужило тројицу Руса за покушај тровања Гебрева.

У вези са тиме, морамо поменути и ДПС (Покрет за права и слободе). Иако „на површини” либерална и проатлантска формација, годинама се чују тврдње да ова етничка партија заправо служи геополитичким интересима Русије у Бугарској (Cholakov, 2018, Minchev, 2016). Сматра се да ДПС има снажан утицај на правосуђе у земљи.

Говор госпође Мустафа у Атлантском клубу у Бугарској важан је због најмање два разлога. Прво, по мом мишљењу, он садржи оцену да Бугарска има системски проблем са корупцијом на највишим нивоима владе. Ова тврдња поткрепљена је чињеницама - Бугарска је стално на врху листе најкорумпиранијих држава чланица ЕУ према Индексу перцепције корупције (CPI) који саставља невладина организација Transparency International (Transparency International, 2020). Речи госпође Мустафа, које су, наравно, израз званичног америчког става, потпуно су супротне покушајима Борисовљеве владе да умањи проблем Бугарске са корупцијом. Друго, говор госпође Мустафа указује на то да, према САД, Бугарској недостаје политичка воља да се ухвати у коштац са метастазом корупције. Бугарске власти су показале да не могу (или не желе) да се „излече”.

Док су спорни докази о умешаности Русије у правосуђе, утицај Кремља на бугарску енергетску индустрију је добро позната чињеница.

Чувена је крилатица руског цара Александра III да „Русија има само два савезника: војску и морнарицу". Ипак, са становишта савремене политичке реалности, можемо навести и трећег савезника - угљоводонике. Енергетика је главна геополитичка алатка којом Москва врши утицај. Енергетска индустрија Бугарске у великој мери зависи од Русије: земља увози више од две трећине природног гаса који троши (Cholakov, 2019d; Shentov, 2018). Компанија Lukoil-Bulgaria, у саставу руске групације Lukoil, највећа је компанија у Бугарској (са учешћем од око 9\% у БДП). Године 2011. је господин Златев, тадашњи директор компаније Lukoil-Bulgaria, посредовао у преговорима за изградњу нуклеарне централе Белене. Влада Руске Федерације је у више наврата дала снажну подршку овом пројекту (Bechev, 2017; Shentov, 2018).

Крајем прве деценије 2000. године Бугарска је имала кључну улогу у настојањима Кремља да кроз југоисточну Европу изгради гасни коридор који ће заобићи Украјину - то је била намера у основи пројеката Плави ток, Северни ток и Јужни ток. Бугарска је била једна од земаља које су биле најугроженије током Друге украјинске гасне 
кризе (6-20. јануар 2009). Поред Јужног тока, још два амбициозна пројекта, као део геополитичке игре Русије, су изградња нуклеарне централе Белене и Трансбалкански гасовод, познат и као нафтовод Бургас-Александрополис.

Пројекат Јужни ток би највероватније био реализован да није уследила украјинска криза, а нарочито руска анексија Крима. Криза је онемогућила постизање компромиса између Гаспрома и Европске комисије (ЕС) о спровођењу правила ЕУ о приступу трећих лица Јужном току. Због тога је премијер Орешарски објавио да ће радови на Јужном току бити обустављени док Русија и Европска комисија не буду постигле договор. Могуће је да је судбина Јужног тока послужила као катализатор за политичку кризу која је почела у Бугарској јуна 2014. године (Bechev, 2017). Ово је довело до распада владајуће коалиције када је ДПС повукао своју подршку влади Орешарског, као и до превремених парламентарних избора у јесен 2014, када је ГЕРБ поново дошао на власт.

Банкрот Корпоративне комерцијалне банке такође се повезивао са замрзавањем пројекта Јужни ток. Главни партнер ове банке - политичар ДПС-а и тајкун Делјан Пеевски - узео је огромне зајмове од банке у намери да учествује у изградњи Јужног тока (Bechev, 2017, str. 107). Могуће је да је после неуспеха пројекта господин Пеевски довео Корпоративну комерцијалну банку до стечаја јер није могао да отплати зајмове (Ibid., str. 107). Такође треба напоменути да постоје докази о покушајима Константина Малофејева да купи TV7 - телевизијски канал под спонзорством поменуте банке (Ibid., str. 107).

Фијаско Јужног тока није окончао зависност Бугарске од руске енергетике. Међутим, постоје извесне препреке за ефикасност руског „енергетског оружја”. Променљиви тржишни услови и притисак из Брисела да се либерализује и диверсификује снабдевање гасом умањују тежину овог инструмента. Гаспром се нашао на мети ЕУ која је 2015. покренула судски поступак против ове компаније због кршења антитрустовских закона.

У октобру 2020. године, Френсис Фанон, амерички заменик државног секретара за енергетику, рекао је да је пројекат који бугарски премијер упорно зове „Балкански ток" заправо део Турског тока 2 ("The US remain against the Belene NPP...", 2020). Сједињене Америчке Државе се противе овом пројекту, као и обнављању нуклеарне централе Белене. Вашингтон је проширио санкције против компанија Тур-

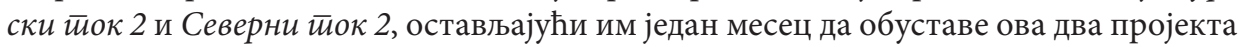
(Karaboev, 2020).

Постоје докази да Турски ток 2 у Бугарској гради Русија, која је преузела саудијски конзорцијум Аркад и ангажовала подизвођаче повезане са Гаспромом (Stanchev, 2020). Буліарйрансїас (бугарски државни оператор система за транспорт гаса) задужен је за нови гасовод Исток-запад (део Турског тока 2 у Бугарској). У суштини, трошкове овог гасовода у износу од 3 милијарде лева плаћају бугарски порески обвезници. Они неће успети да у догледној будућности врате своју „инвестицију” јер је Гаспром резервисао отприлике 90 процената пропусног капацитета током наредних 20 година. Укратко, нетачне су тврдње бугарске владе да ради на енергетској диверсификацији, то јест на смањењу зависности бугарског енергетског сектора од Русије. 


\section{Закључци}

Реаговање бугарског политичког система на кризу у Украјини представља значајан елемент вечитог питања у вези са улогом Русије у бугарској политици. За разлику од читавог низа бугарских влада које су до сада - бар на површини - поштовале ставове ЕУ и НАТО о украјинској кризи, бугарски председници се никада нису слагали у том погледу. Немогуће је занемарити разлику између политичких агенди председника Плевнелијева и Радева: први је ватрени поборник Атлантског савеза, док је други заговорник уравнотежене спољне политике.

Бугарска мора да заштити права и интересе бугарске мањине у Украјини. У том погледу, став бугарског парламента против планиране административне реформе у Одеси у мају 2020. био је добро промишљен и адекватан. За Софију је важно мирно решење сукоба на Црном мору. Такође је јасно, имајући у виду чврсте економске и културолошке везе између Бугарске и Русије, да Бугарска може много изгубити у случају погоршања односа између Софије и Москве.

Истражујући политику Радева односно Борисова, стекли смо утисак да бугарске институције често покушавају да умире како Москву, тако и Вашингтон. Парадоксална дихотомија одражава ставове великог дела бугарских гласача. Почетком 2015. године, 74\% Бугара оценило је политику владе у односу на украјинску кризу као „умерену и уравнотежену” (Alpha Research, 2015). Међутим, студија коју је Истраживачки центар Пју спровео у деветнаест земаља, од којих су шеснаест чланице НАТО, показује да је Бугарска земља која више воли везе са Русијом него са Сједињеним Америчким Државама (Fagan\&Poushter, 2020). Две трећине Бугара одбацују војну интервенцију своје земље као подршку некој савезници НАТО „у случају руске агресије” (Ibid.). Осим тога, испоставило се да су Бугари „шампиони” у „наклоности према Путину” - чак $62 \%$ њих „имају поверење” у руског председника (Ibid.).

Колико је, међутим, реално да се спољна политика Бугарске руководи према принципу „увек са НАТО, никад против Русије”?

Ова земља је већ направила свој избор; геополитичка коцка је бачена: Бугарска је чланица НАТО од 2004. и чланица ЕУ од 2007. године. И Атлантски пакт и ЕУ осуђују улогу Москве у украјинском сукобу. Истовремено, тврдње о умешаности Кремља у политичке процесе у Сједињеним Америчким Државама и на другим местима, афера Скрипаљ, база руских шпијуна откривена у Алпима 2019. године, међусобне оптужбе за тровање руског опозиционог лидера Наваљног у лето 2020. и остали догађаји показују да расту тензије између Русије, с једне стране, и Брисела и Вашингтона, с друге.

Бугарска све више изгледа као држава на првој линији фронта на територији око које су се сукобили НАТО и Кремљ.

Бугарска не треба да прекине све везе са Русијом нити да клечи пред својим „новим” партнерима у спољној политици. Међутим, Софија мора да схвати да су, због све дубљег непријатељства између блокова, двосмислени спољнополитички ставови крајње неадекватни. Бугарска треба да се чвршће придржава курса који су усвојили НАТО и ЕУ, а нарочито може да има користи од ослобађања енергетске индустрије од „надзора” Москве. 


\section{REFERENCES / ЛИTEPATУPA:}

Alpha Research. (2015). Bulgarian foreign policy, the Russia-Ukraine conflict and our national security. Public attitudes February-March 2015. Sofia: Alpha Research. Available at:http://alpharesearch.bg][In Bulgarian]

A MP from the BSP: “Happy victory in the Third Crimean War!”. (2014, March 19). Darik News. Available at:https://dariknews.bg[In Bulgarian]

Bechev, D. (2017). Rival Power. Russia Influence in Southeast Europe. New Haven and London: Yale University Press.

Bechev, D. (2020, November 2). Turk Stream 2 or Balkan Stem? Either way Moscow is the main beneficiary. Middle East Institute. Available at:https://www.mei.edu

Brecher, M. (1996). Introduction: Crisis, Conflict, War: State of the Discipline. International Political Science Review, Vol. 17, No. 2, Crisis, Conflict and War, (Apr., 1996), 127-139.

BSP: "Vision for Bulgaria". (2019). Available at:https://bsp.bg[In Bulgarian]

Cholakov, P. (2018). Ethnic Entrepreneurs Unmasked: Political Institutions and Ethnic Conflicts in Contemporary Bulgaria. Stuttgart: Ibidem Press.

Cholakov, P. (2019a, November 29). Bulgaria has a serious problem. These words of Herro Mustafa say everything. Deutsche Welle. Available at:https://www.dw.com[In Bulgarian]

Cholakov, P. (2019b, September 11). Will all dark threads connecting Russia with Bulgaria come into light?. Deutsche Welle. Available at https://www.dw.com [In Bulgarian]

Cholakov, P. (2019c, March 27). Always with NATO, never against Russia?. Deutsche Welle. Available at https://www.dw.com[In Bulgarian]

Cholakov, P. (2019d, February 28). Russia’s proposed Turk Stream 2 pipeline sparks Bulgaria, EU energy worries. Deutsche Welle. Available at; https://www.dw.com

Cholakov, P. (2020a, October 21) Radev and the Estonian scandal - irresponsibility or a conspiracy?. Deutsche Welle. Available at:https://www.dw.com [In Bulgarian]

Cholakov, P. (2020b, September 23). The great replacement for which Russia works. Deutsche Welle. Available at: https://www.dw.com In Bulgarian]

Dimitrov, P. (2017). Keeping up with Brussels. The Bulgarian Reaction to the Ukrainian Crisis. In: Marinkov, B., Banchev, B. (eds.) The Ukrainian Crisis and the Balkans (pp. 94-118). Sofia: Paradigma. [In Bulgarian]

Drumeva, I., Ginkova. Al. (2020, September 23). The Prosecutor's Office has found two more Russian spies. Dnevnik. Available at:https://www.dnevnik.bg][In Bulgarian]

Engdahl, F. W. (2018). The Geopolitical Dimensions of the Three Seas Initiative. Geopolitics, 2018, March 20. Available at:https://geopolitica.eu[In Bulgarian]

Exacta: 28\% of BSP voters do not want us in the EU, and 40\% - in NATO (2018, April 26). OffNews. Available at: https://offnews.bg [In Bulgarian]

Fagan, M., Poushter, J. (2020). NATO Seen Favorably across Member States. Pew Research Centre. 2020, February 9. Available at:https://www.pewresearch.org

Galeotti, M. (2017). From Trump's Washington to the Capitals of Europe, Corruption is Russia’s Greatest Ally. In Moscow's Shadows blog. 2017, March 3. Available at:https:// inmoscowsshadows.wordpress.com.

Gerasimov, V. (2013). The Value of Science is in Making Forecasts, VPK (www.VPK-News.ru), No. 8, 476, 1-3. Available at:https://vpk-news.ru [In Russian]. 
Goldman, M. (2008). Petrostate: Putin, Power, and the New Russia. Oxford: Oxford University Press.

Gunkel. E. (2020, September 4). How Emilian Gebrev's Poisoning Tests Disappeared?, Deutsche Welle. Available at https://www.dw.com [In Bulgarian]

Holmes, L. (2015, November 15). Russia plans a 'hybrid warfare' campaign aimed at destabilising Europe, says Bulgarian President. The Independent. Available at:https://www. independent.co.uk.

Kalan, D. (2015, June 9). Bulgaria’s Turn. Sofia gives Moscow some Attitude. Foreign Affairs.

Karaboev, P. (2020, October 21). The United States has expanded the scope of sanctions against the Turkish Stream. Dnevnik. Available at:https://www.dnevnik.bg [In Bulgarian]

Kuras, I., Pirozhkov, S., eds. (2004). First All National Population Census. Kyiv: Institute for Demography and Social Studies. NAS of Ukraine and State Statistics Committee of Ukraine. Available at:http://2001.ukrcensus.gov.ua

Lavrov called the Bulgarian ambassador to Russia: Two Bulgarian diplomats have been declared persona non grata (2020, December 12). Deutsche Welle. Available at:https:// www.dw.com [In Bulgarian]

Lalov, N. (2017, October 5). Gripen Commission talks about "Samoletgate" and hints towards Radev's corruption. Mediapool. Available at:https://www.mediapool.bg [In Bulgarian]

Malofeev, K. (2019, January 13). We are against democracy, we will live according to our traditions. Facotor.bg. Available at:https://www.faktor.bg][In Bulgarian]

Minchev, Ogn. (2016, January 8). The biggest winner is Dogan. Mediapool. Available at: https://www.mediapool.bg [In Bulgarian]

Mitov, B. (2020, May 31). Vindication? Ex-Minister Takes Aim At Bulgaria's 'Totalitarian Instinct'. RFERL. Available at:https://www.rferl.org

Mitov, D. (2016, Spetembre 7). "Bulgaria will vote to keep the sanctions against Russia" Trud. Available at https://trud.bg[In Bulgarian]

Popov, A. (2015, July 26). The Agriculture loses 82 million lev because of the Russian embargo. Dnes.bg. Available at:https://www.dnes.bg In Bulgarian]

Radev sharply criticizes the F-16 deal, sees emerging "authoritarianism". (2019, June 28). Club Z. Available at:https://clubz.bg In Bulgarian]

Rumen Radev announced the lifting of sanctions against Russia. (2017, January 13). bTV. Available at: https://btvnovinite.bg [In Bulgarian]

Russian General Reshetnikov: Ninova and I discussed Radev's nomination. (2016, November 24). News.bg. Available at:https://news.bg[In Bulgarian]

Rusenova, V. (2019, June 5). Radev: our cooperation with Russia must develop despite sanctions. Vesti.bg Available at https://www.vesti.bg [In Bulgarian]

Shentov, O. ed. (2018). The Russian Economic Grip on Central and Eastern Europe. Routledge.

Stanchev, Iv. (2020, October 16). How Russia took the gas pipeline and BGN 3 billion. Capital. Available at: https://www.capital.bg In Bulgarian]

The United States remains against the Belene NPP and the continuation of the Turkish Stream in Bulgaria. (2020, October 1), BNR. Available at:https://bnr.bg [In Bulgarian] 


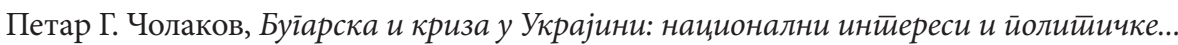

Transparency International (2020). Corruption Perceptions Index, 2019. Available at:https:// www.transparency.org

Trenin, D. (2019). From hybrid war to mutual exclusion. How relations between Russia and the United States changed in 20 years. Moscow Carnegie Centre. Available at:https:/ carnegie.ru[in Russian].

Veselinova, M. (2019, February 11). The authorities finally began talking about Gebrev's poisoning. Capital. Available at https://www.capital.bg [In Bulgarian]

Who is Reshetnikov and for which investigation were the Russophiles questioned. (2019, September 10). Free Europe. Available at:https://www.svobodnaevropa.bg [In Bulgarian] 